http://doi.org/10.35784/iapgos.1564

\title{
REAL-TIME MONITORING OF CELL CULTURES WITH NICKEL COMB CAPACITORS
}

\author{
Andrzej Kociubiński ${ }^{1}$, Dawid Zarzeczny ${ }^{1}$, Maciej Szypulski ${ }^{1}$, Aleksandra Wilczyńska ${ }^{1}$, Dominika Pigońn ${ }^{2}$, \\ Teresa Małecka-Massalska², Monika Prendecka ${ }^{2}$ \\ ${ }^{1}$ Lublin University of Technology, Lublin, Poland, ${ }^{2}$ Medical University of Lublin, Lublin, Poland
}

Abstract. The aim of the study was to present a method for assessing the condition of cell culture by measuring the impedance of cells cultured in the presence of nickel. For this purpose, an impedance measurement technique using nickel comb capacitors was used. The capacitor electrodes were made using a thin film magnetron sputtering. In the experimental part, the culture of cells of mouse fibroblasts on the prepared substrate was performed. The cell culture lasted 43 hours and showed that the presented technique allows it to be used to analyze the effect of nickel on cells.

Keywords: BioMEMS, ECIS, nickel, thin films

\section{MONITOROWANIE HODOWLI KOMÓRKOWYCH W CZASIE RZECZYWISTYM PRZY ZASTOSOWANIU NIKLOWYCH KONDENSATORÓW GRZEBIENIOWYCH}

\begin{abstract}
Streszczenie. Celem pracy było przedstawienie metody oceny stanu hodowli komórkowej poprzez pomiar impedancji komórek hodowanych w obecności niklu. W tym celu zastosowano technike pomiaru impedancji z wykorzystaniem niklowych kondensatorów grzebieniowych. Cienkowarstwowe elektrody kondensatora wykonano metoda rozpylania magnetronowego. W części eksperymentalnej przeprowadzono hodowle komórek mysich fibroblastów na przygotowanym podłożu. Hodowla komórkowa trwała 43 godziny $i$ wykazała, że przedstawiona technika mogłaby być zastosowana do analizy wplywu niklu na komórki.
\end{abstract}

Slowa kluczowe: BioMEMS, ECIS, nikiel, cienkie warstwy

\section{Introduction}

Impedance measurement methods can be used to assess cell status. These techniques are non-invasive and label-free electrochemical, enabling to obtain sensitive and quantitative results. The most typical are three measurement techniques [10]:

a) impedance flow cytometry,

b) electric impedance spectroscopy,

c) electric cell-substrate impedance sensing (ECIS).

These methods are based on impedance measurement, which is defined as the complex ratio of the voltage to the current in an alternating/direct current circuit. Usually a small sinusoidal AC signal is used as excitation and the electrical current response is measured. During the measurement, biological cells are suspended in medium or adhered to a substrate. To properly analyze the cellmedium-electrode system, models of electrical circuits were created. Research work presented in this paper relates to the ECIS technique, which is based on a single-shell model, in which the cell membrane blocks the current when cells adhere to the electrodes of the substrate. Due to cell proliferation and spreading, the measured impedance changes [4]. The possibility of long-term monitoring of cell culture means that it is a method which can be widely used in biological research.

\section{ECIS to monitor cell status}

The technique of monitoring cell culture using impedance measurement in the ECIS system is based on the use of thin-film capacitors produced on a biocompatible substrate. This technique has already been used for various types of researches: cell apoptosis [2], cell proliferation [11], drug screening [6], toxicity testing [9], cancer research [5] and stem cell differentiation [3].

Figure 1 shows typical resistance and capacitance characteristics (impedance components) for a cell culture cycle on the example of animal fibroblasts. When cells are added to the medium, the number of cells is increased by cell growth and division. Impedance increases as a result of the increase of electrodes area covered with a non-conductive cell membrane (phase 1). The number of cells is closely related to the corresponding normalized impedance value [1]. Cell proliferation and cell apoptosis or necrosis change the morphology of the cells that cover the electrodes, and thus can be detected quantitatively. During phase 2, cell culture stabilizes. And in phase 3, cells die, their adhesion decreases, therefore in the measurement circuit electrical resistance decreases, and capacity increases.
The fabrication of electrodes requires the use of microelectronic technologies, because their size should be about the size of biological cells $(\sim 10 \mu \mathrm{m}$ in diameter). The biocompatible test substrate with capacitor electrodes is the main sensor element of the ECIS system. Polyethylene terephthalate (PET) and polycarbonate (PC) are used as the starting substrate. Thin film electrodes are usually fabricated of gold or platinum due to their biocompatible properties and good electrochemical parameters.

The measuring capabilities of the ECIS system also allow testing the effect of the presence of various metals on cell cultures. However, it is necessary to produce dedicated test substrates with thin-film capacitors made of various materials. Some other metals offer different chemical, physical and electrical properties than gold and platinum, which are also the expensive materials. In biomedical microdevices, metal elements are also made of nickel, aluminum, tungsten, silver alloys, aluminum alloys and IndiumTin Oxide (ITO) [7].

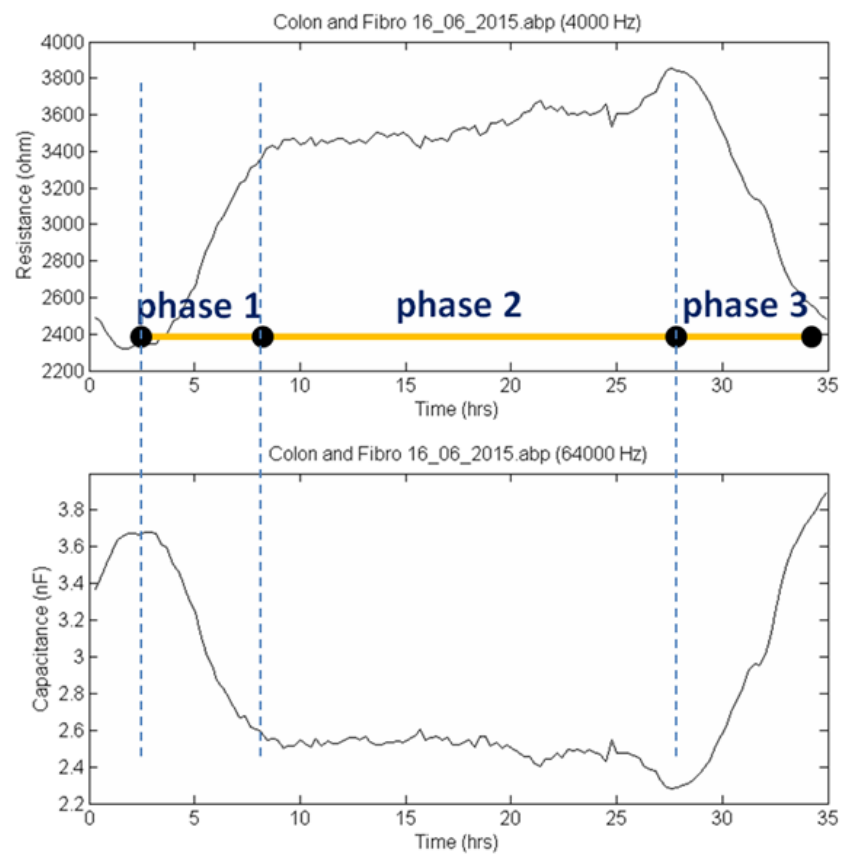

Fig. 1. Resistance (top) and capacitance (bottom) characteristics of mouse fibroblast cells measured by a standard ECIS sensor array at $4 \mathrm{kHz}$ and $64 \mathrm{kHz}$, respectively 
The main problem in the selection of material in biomedical applications is the assessment of the impact of its presence on the tested cells or substances [8]. Biocompatibility is a very important issue, especially for implants intended for long-term use. The materials used in BioMEMS devices usually have lower requirements, but also need to be tested for toxicity, degradation, corrosion and dissolution at ambient temperature. There are many applications in which the contact of substances of biological origin with metallization is short-lived and often one-off, e.g. physiological and biochemical sensors, devices for drug delivery. In such cases, it seems advisable to use a cheaper material, even if it is less biocompatible than gold or platinum typically used. The aim of this work is to perform a test culture on the made substrate with nickel electrodes, expecting that the obtained results of electrical parameters should be similar to a typical cell culture on a commercial substrate with gold electrodes. The prepared substrates can be used to test the effect of metal on biological substances using the ECIS measuring platform to monitor the condition of cells cultured in the presence of nickel electrodes. In addition, they will replace highly biocompatible materials with a less biocompatible but cheaper replacement.

\section{Technology and experimental cultures}

\subsection{Technology of nickel electrode array}

As part of an experiment analyzing the effect on a cell culture of a material other than gold or platinum, a test substrate with nickel capacitors was produced. The preparation of test substrates required a number of works in the field of thin film structure manufacturing technology. First, technological masks have been designed based on an electrode array with eight wells. The individual electrodes were made as comb capacitors in which the width of a single finger was $200 \mu \mathrm{m}$.

The biocompatible substrate was cut out of $2 \mathrm{~mm}$ thick polycarbonate. The key step was the deposition of a nickel layer $(100 \mathrm{~nm})$ in the magnetron sputtering process using a Kurt J. Lesker NANO $36^{\mathrm{TM}}$ device. The magnetron sputtering technique is based on the phenomenon of individual particles deposition of material evaporated from the source under the influence of ionized energy by a strong electric field of gas. A vacuum is required to perform the deposition process. During the process, high temperatures are not used that would damage the base material (melting or polymerization). In this case, the process temperature does not exceed $60-70^{\circ} \mathrm{C}$. Standard semiconductor technology uses a silicon monocrystalline substrate and the process temperatures reach above $1000^{\circ} \mathrm{C}$.

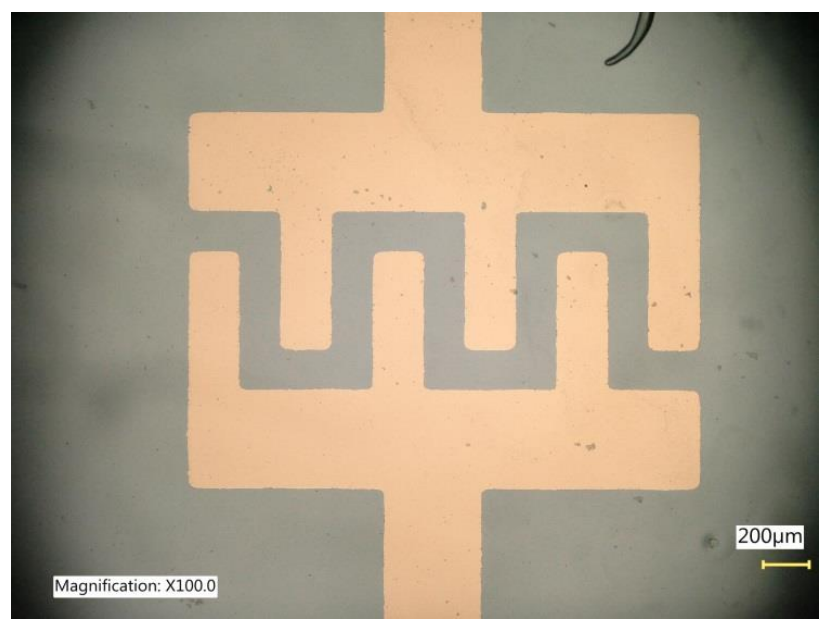

Fig. 2. Nickel comb capacitor on a biocompatible polycarbonate substrate

Positiv 20 photosensitive emulsion was used for the photolithography process. The emulsion was heated and exposed by UV radiation through the mask. Next, the etching of the metallization layer were carried out. Finally, the substrate was washed with deionized water in an ultrasonic cleaner (Fig. 2).
Special wells were placed on the electrodes and fixed using a biocompatible silicone. Each of the 8 wells with a volume of $0.6 \mathrm{~cm}^{3}$ and a substrate area of $0.8 \mathrm{~cm}^{2}$ contains a single comb active electrode (Fig. 3). The wells were exposed bactericidal ultraviolet radiation to sterilize the set.

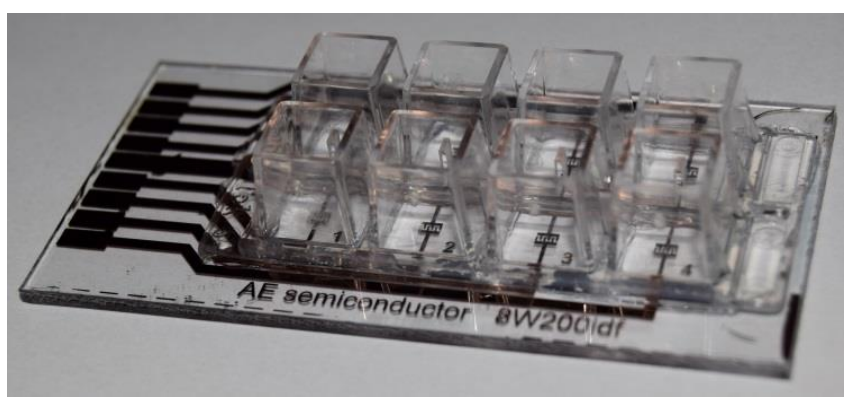

Fig. 3. The final nickel electrode array with 8 wells

\subsection{Preparation of the cell culture test}

An experimental culture of animal cells was performed on the prepared testing substrate. For this purpose, cells of mouse fibroblast cell line were used. It was NCTC clone 929 [L cell, L929, derivative of Strain L] (ATCC® CCL-1 ${ }^{\mathrm{TM}}$ ) derived from ATCC organization which were cultured according to the instruction manual in complete Eagle MEM medium (Sigma Aldrich) supplemented with 10\% Fetal Bovine Serum (FBS) Good $\mathrm{HI}$, in an Galaxy 170R incubator, under controlled growth conditions, constant humidity and air saturation of $5 \% \mathrm{CO}_{2}$ (Fig. 4)

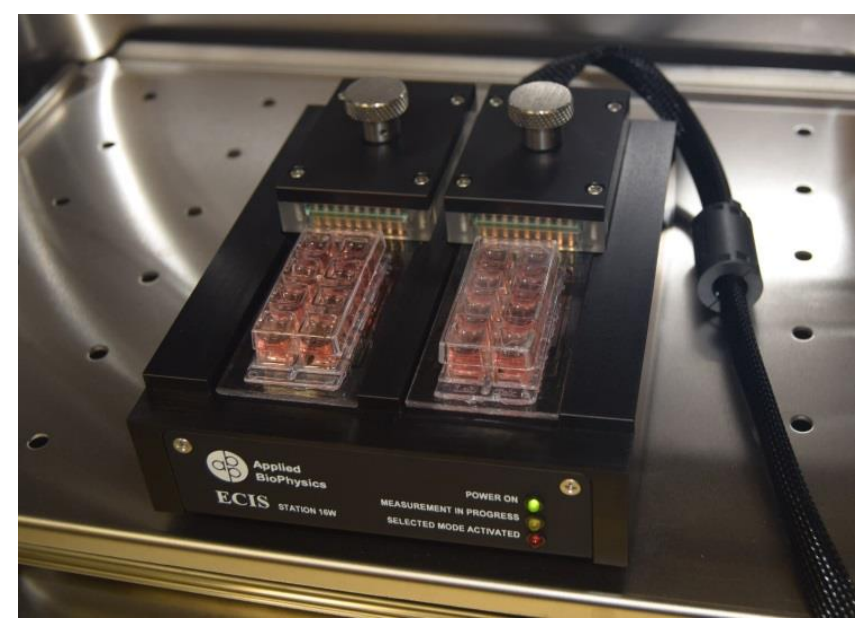

Fig. 4. The electrode array placed in the ECIS holder in the climatic chamber

The stabilization of conditions lasted 24 hours after placing the medium in the wells. Inoculation of arrays was carried out by $0.3 \mathrm{~cm}^{3}$ per well of cell suspension at $\sim 1.2 \times 10^{5} \mathrm{cell} / \mathrm{cm}^{3}$. When the cells will be introduced to the well, they drift to the bottom of the dish where they attach and then spread on both the nickel electrodes and the polycarbonate surfaces.

\section{Results and discussion}

\subsection{The results of electrical parameters measurements}

During the experiment, the results of measuring resistance, capacitance and impedance were collected for a signal frequency in the range $62.5 \mathrm{~Hz}-64 \mathrm{kHz}$. The experiment lasted for 43 hours. However, only the results obtained for the first 18 hours are interpretable. The obtained values were normalized and presented as their changes during cell culture. Each parameter reading is plotted as a point, in ohms for resistance and impedance or nanofarads for capacitance, in dependence of time. 


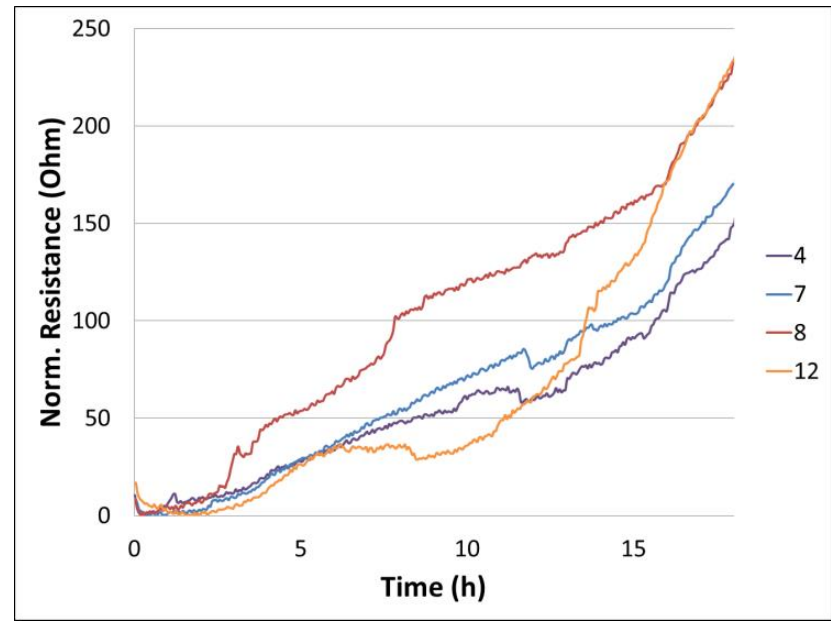

Fig. 5. Resistance response measured by a nickel sensor array at $62.5 \mathrm{~Hz}$ for 18 hours

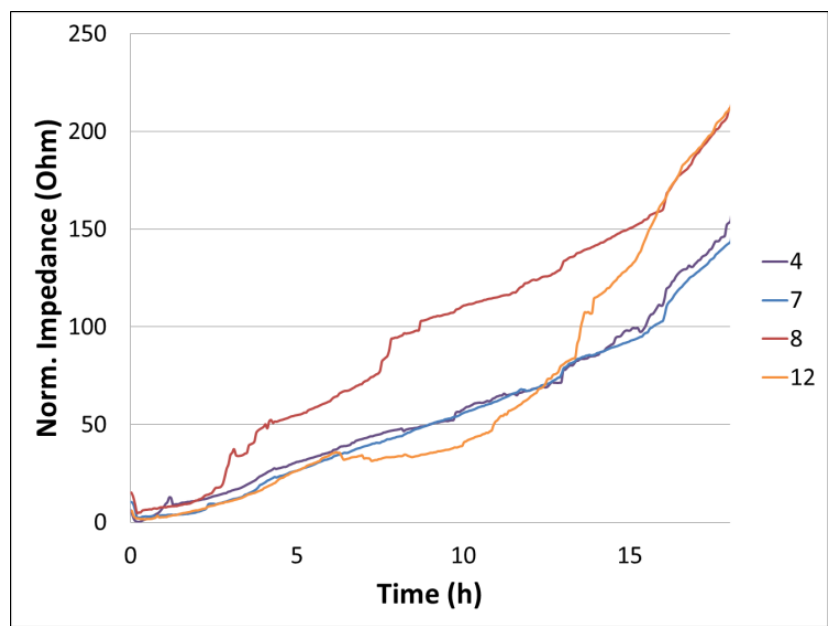

Fig. 6. Impedance response measured by a nickel sensor array at $4 \mathrm{kHz}$ for 18 hours

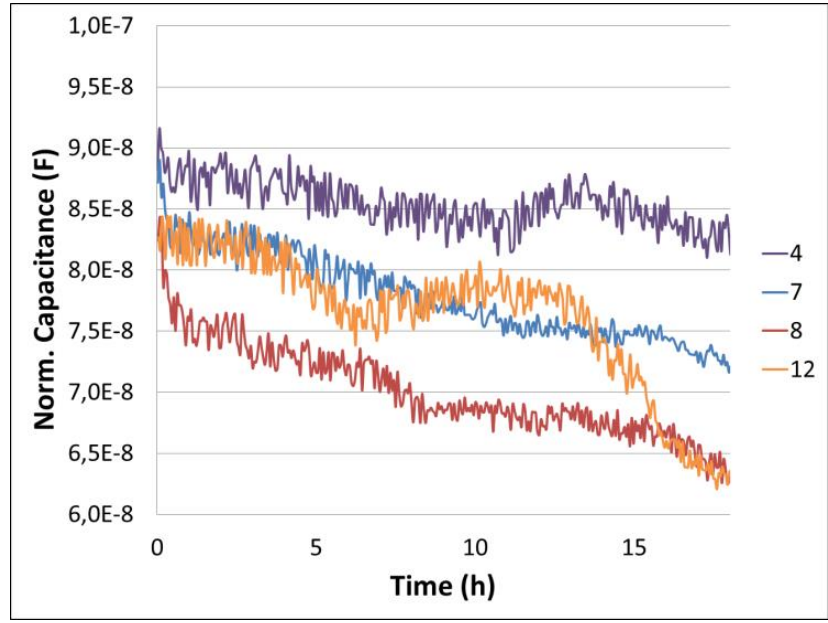

Fig. 7. Capacitance response measured by a nickel sensor array at $64 \mathrm{kHz}$ for 18 hours

Fig. 5 shows the values of the resistance as a function of frequency for four typical electrodes It was found that resistance increased to $\sim 150-200 \mathrm{ohms}$ in the first 18 hours. This indicates relatively good cell viability and proliferative potential. The resistance represents the quality and function of the cell barrier and therefore takes into consideration the resistance towards para- and trans-cellular current flow. Similar fluctuations were observed for impedance at $4 \mathrm{kHz}$ (Fig. 6).

At much higher frequency, the current start to flow through the cells because of the high capacitance of the cell membranes. Capacitance measurement results refer to an overall measure of electrode coverage. The decrease in capacity (Fig. 7) achieved during the initial 18 hours with increasing resistance should be interpreted as cell proliferation and in this respect both values complement each other and should be analyzed in parallel as a standard.

\subsection{Metallization layer damage}

After more than 20 hours of the cells growing, there was a sharp increase in resistance (Fig. 8) and impedance. Cell culture was continued for up to 43 hours despite receiving unusual results.

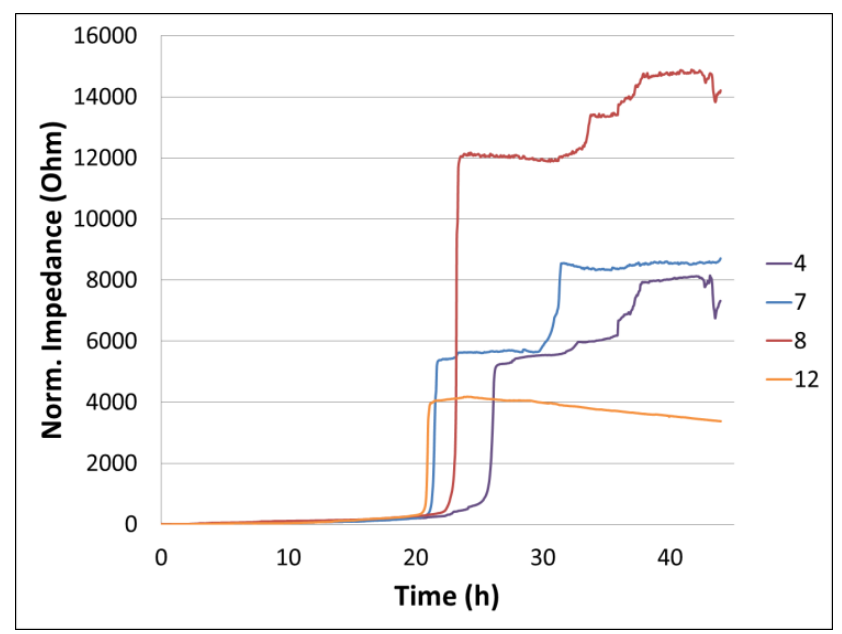

Fig. 8. Impedance response measured by a nickel sensor array at $4 \mathrm{kHz}$ for 45 hours

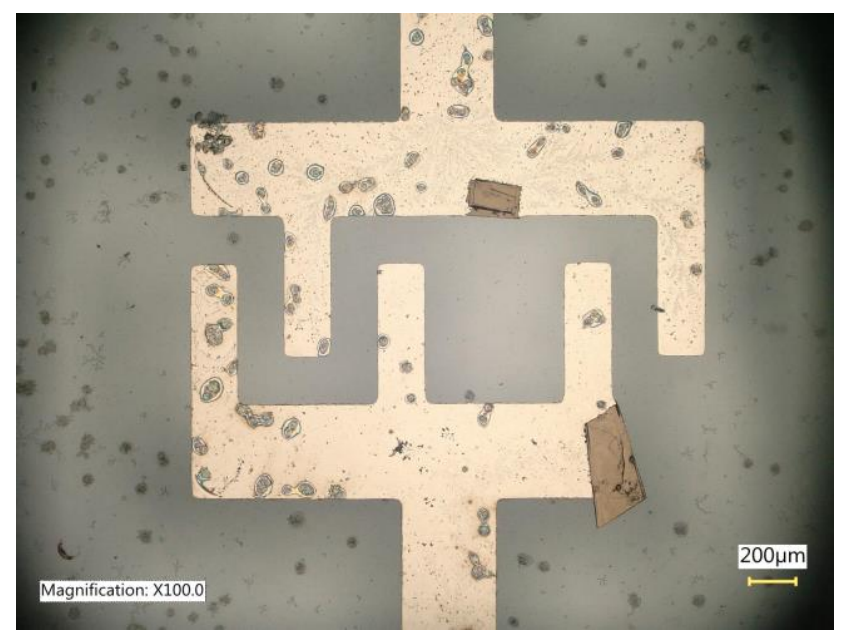

Fig. 9. Damaged nickel capacitor electrode without cells in the reference well after 67 hours (24 h stabilization of medium conditions and $43 \mathrm{~h}$ cell culture)

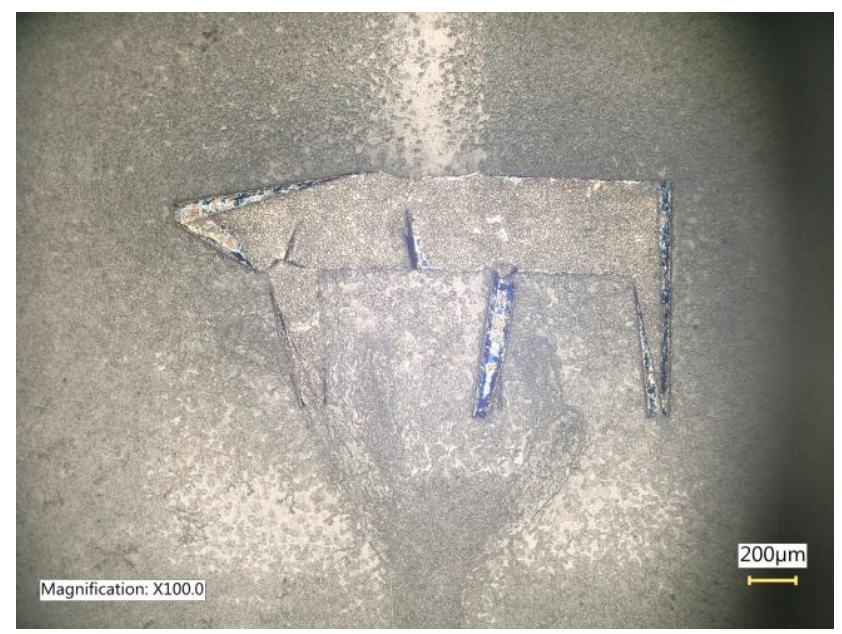

Fig. 10. Damaged nickel capacitor electrode with cells after 67 h (24 h stabilization of medium conditions and 43 h cell culture) 
After the experiment microscopic images of the capacitor electrodes were taken (Fig. 9-10). They showed that during cell culture the metallization layer lost its adhesion to the substrate, which resulted in a rapid increase in the measured resistance.

However, during this time the second phase is visible, i.e. the stabilization of cell culture. After about 42 hours, the third phase ( 4 and 8 wells) begins, which is characterized by a decrease in the value of the measured resistance.

\section{Conclusions and future work}

In this paper, the developed measuring substrate technology with thin-film nickel capacitors is demonstrated. The substrates were checked for compatibility with the ECIS system. To verify that the presence of nickel would allow monitoring of vital functions of cells, the L929 cell line was performed. The obtained results of the electrical parameters show that after adding the cells to the wells, a typical cell culture cycle can be observed. This indicates the possibility of use of a substrate with nickel capacitors to analyze the effect of this metal on cell culture. And in the future it will allow the use of cheaper material in many applications.

\section{References}

[1] Arias L.R., Carla A.P., Yang L.: Real-Time Electrical Impedance Detection of Cellular Activities of Oral Cancer Cells. Biosensors and Bioelectronics 25(10), 2010, 2225-2231 [http://doi.org/10.1016/j.bios.2010.02.029].

\section{Ph.D. Andrzej Kociubiński}

e-mail: akociub@semiconductor.pl

He received the M.Sc. and Ph.D. degrees in electronic engineering from Warsaw University of Technology, Poland. In 2007 he joined the Lublin University of Technology (Poland), where he was involved in research on semiconductor technology. His research interest is concentrated on semiconductor devices and technology. His recent activities are related to microsystems for biomedical applications.

http://orcid.org/0000-0002-0377-8243

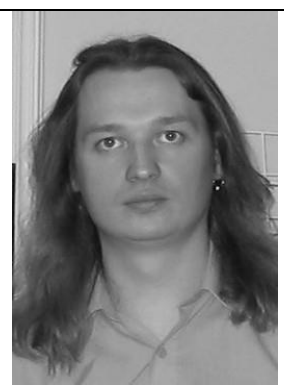

M.Sc. Eng. Dawid Zarzeczny

e-mail: dawid.adrian.zarzeczny @ gmail.com

He graduated in Mechatronics at the Lublin University of Technology. Ph.D. student at the Lublin University of Technology at the Department of Electronics and Information Technology. His research area focuses on microeletronics, semiconductor technology and biomedical engineering. He is the author or co-autho over 16 articles in the field of in the field of designing microelectronic devices and testing the electrical properties of cells culture.

http://orcid.org/0000-0003-2029-9962

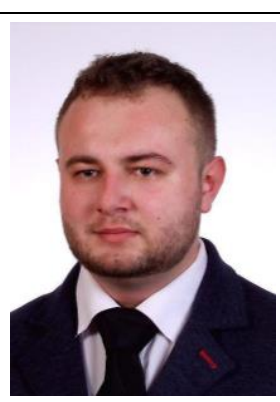

M. Sc. Eng. Maciej Szypulski

e-mail: szypulski.maciej@gmail.com

A graduate of Mechatronics at the Lublin University of Technology (2017). Currently a PhD student at the Lublin University of Technology. His main scientific interests are the use of MEMS technologies in applications in the field of bioengineering for local temperature change.

http://orcid.org/0000-0002-6227-3624

\section{Eng. Aleksandra Wilczyńska}

e-mail: aleksandra.wilczynska9@gmail.com

Master student of mechatronics at the Faculty of Electrical and Computer Science of the Lublin University of Technology. She received Eng. biomedical engineering degrees at the Faculty of Mechanical Engineering of the Lublin University of Technology.
[2] Arndt S., Seebach J., Psathaki K., Galla H.J., Wegener J.: Bioelectrical Impedance Assay to Monitor Changes in Cell Shape during Apoptosis Biosensors and Bioelectronics 19(6), 2004, 583-594 [http://doi.org/10.1016/S0956-5663(03)00269-0].

[3] Bagnaninchi P.O., Drummond N.: Real-Time Label-Free Monitoring of Adipose-Derived Stem Cell Differentiation with Electric Cell-Substrate Impedance Sensing. Proceedings of the National Academy of Sciences of the United States of America 108(16), 2011, 6462-6467 [http://doi.org/10.1073/pnas.1018260108].

[4] Giaever I., Keese C.R.: A Morphological Biosensor for Mammalian Cells. Nature 366(6455), 1993, 591-592 [http://doi.org/10.1038/366591a0].

[5] Hong J., Kandasamy K., Marimuthu M., Choi M.S., Kim S.: Electrical CellSubstrate Impedance Sensing as a Non-Invasive Tool for Cancer Cell Study. The Analyst 136(2), 2011, 237-245 [http://doi.org/10.1039/C0AN00560F].

[6] Hug T.S.: Biophysical Methods for Monitoring Cell-Substrate Interactions in Drug Discovery. ASSAY and Drug Development Technologies 1(3), 2003, 479-488 [http://doi.org/10.1089/154065803322163795].

[7] Scholten K., Meng E.: Materials for Microfabricated Implantable Devices: A Review. Lab on a Chip 15(22), 2015, 4256-4272 [http://doi.org/10.1039/C5LC00809C].

[8] Stensaas S.S., Stensaas L.J.: Histopathological Evaluation of Materials Implanted in the Cerebral Cortex. Acta Neuropathologica 41(2), 1978, 145-155 [http://doi.org/10.1007/BF00689766].

[9] Xiao C., Luong J.H.T.: On-Line Monitoring of Cell Growth and Cytotoxicity Using Electric Cell-Substrate Impedance Sensing (ECIS). Biotechnology Progress 19(3), 2003, 1000-1005 [http://doi.org/10.1021/bp025733x].

[10] Xu Y., Xie X., Duan Y., Wang L., Cheng Z., Cheng J.: A Review of Impedance Measurements of Whole Cells. Biosensors and Bioelectronics 77(March), 2016 824-836 [http://doi.org/10.1016/J.BIOS.2015.10.027].

[11] Zudaire E., Cuesta N., Murty V., Woodson K., Adams L., Gonzalez N., Martínez A., Narayan G., Kirsch I., Franklin W., Hirsch F., Birrer M. Cuttitta F.: The Aryl Hydrocarbon Receptor Repressor Is a Putative Tumor Suppressor Gene in Multiple Human Cancers. Journal of Clinical Investigation 118(2), 2008, 640-650 [http://doi.org/10.1172/JCI30024].

\section{M.Sc. Dominika Pigoń}

e-mail: dominikapigon@umlub.pl

She received the M.Sc. in biology with microbiology specialization at Maria Curie-Skłodowska University, Lublin, Poland in 2017.

The same year she joined the Medical University of Lublin (Poland), where she is involved in research on cell cultures lifetime monitoring by ECIS (Electric Cell-substrate Impedance Sensing). Her research interest is concentrated on anticancer activity of natural compounds.

http://orcid.org/0000-0002-7545-3237

\section{Prof. Teresa Małecka-Massalska}

e-mail: tmalecka@gmail.com

Internal medicine and rheumatology specialist, head of the Human Physiology Department, Medical University of Lublin, Poland (2014-present), a research fellow at Renal Research Institute, BethIsrael Dialysis Center, Dialysis Department, New York, author and translator of the books for biomedical engineering students. Since 2009 she has been involved into the research of malnutrition in patients with head and neck cancers and since 2016 in ECIS which is an advanced in vitro impedance measuring system to determinate behavior of the cells in physiological conditions.

http://orcid.org/0000-0003-3384-0324

\section{Ph.D. Monika Prendecka}

e-mail:m.prendecka@gmail.com

Assistant professor at the Medical University of Lublin, Physiology Department. She graduated as M.Sc. in 1997 in biochemistry and then Ph.D. in 2003 at the Maria Curie-Skłodowska University in Lublin. She completed post-graduate studies "Project management of the research and development", "Public relations in scientific research" and "Manager of research projects" at the Higher School of Economy and Innovation in Lublin. She does research about biological properties of fungal extracts is their antitumor activity by the monitoring of the electric parameters in cell cultures.
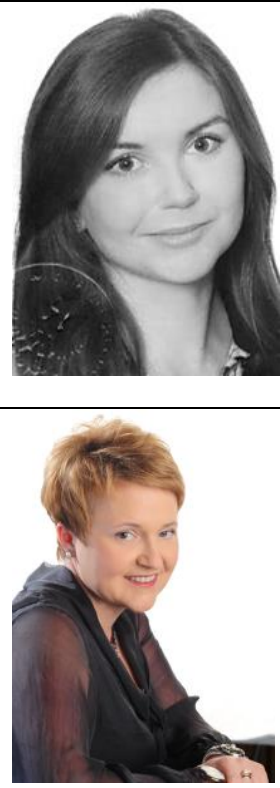

http://orcid.org/0000-0001-9414-4344

otrzymano/received: $20.03 .2020 \quad$ przyjęto do druku/accepted: 26.06 .2020

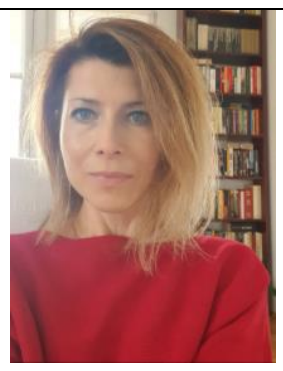

